Law in the Digital Age. 2021. Vol. 2, no. 3.

Вопросы права в цифровую эпоху. 2021. Т. 2. № 3.

Research article

УДК 347.785 .6

DOI: $10.17323 / 2713-2749.2021 .3 .58 .76$

\title{
The Usage of Musical Works in the Internet within the Russian Law: a Comparative Analysis within the Law of US and EU
}

\section{同Erik R. Valdez-Martinez}

National Research University Higher School of Economics. Moscow, Russia. evaldes@hse.ru. https://orcid.org/0000-0001-9958-6395

\section{典目 Abstract}

The article analyzes the "making available" power presented in Russian copyright law, as well as the specifics of obtaining permission to use musical works and phonograms on the Internet. The right to "make available" has been known to Russian law since 2004. This eligibility appears to be very close to the traditional uses of works that existed long before the advent of the Internet. These include, in particular: public performance, broadcasting and cable retransmission. At the same time, "making available" power is presented in Russian law less fully than the indicated powers. The Civil Code of the Russian Federation describes in sufficient detail the mechanism for obtaining permission by users of musical works and phonograms in the case of their public performance, broadcasting or cable retransmission. In particular, broadcasting organizations, which include radio stations and television companies, as well as users of the public sphere, such as theaters, museums, cinemas, etc., are authorized for the respective uses of works and phonograms through collective rights management organizations. Such organizations represent the interests of rightholders when interacting with users and conclude either licensing agreements or agreements on the payment of remuneration with the latter. Among other things, the Civil Code provides for certain cases of endowing collective rights management organizations with accreditation, which allows issuing permission from an unlimited circle of rightholders, including foreign ones, as well as those who have not entered into an agreement on the management of rights with such an organization. At the same time, recently more and more works and phonograms are distributed on 
the Internet. Online cinemas, TV channels, theaters, museum exhibitions, etc. are gaining wide popularity. These resources also use musical works and phonograms, similar to using offline. However, it should be noted that there is legal uncertainty in Russian law related to the mechanism for obtaining permission to use works and phonograms on the Internet. The content of the powers presented in the law of Russia for making a work available, its public performance, broadcasting, communicating by cable, as well as the scope of accreditation, do not allow us to unambiguously conclude about the application of the existing mechanism for obtaining permission through the relevant collective management organizations.

\section{O-4国 Keywords}

Internet, public performance, broadcasting, cable retransmission, retransmission, making available, communication to the public

For citation: Valdes-Martines E.R. The Usage of Musical Works in the Internet within the Russian Law: a Comparative Analysis within the Law of US and EU. Legal Issues in the Digital Age. 2021, vol. 2, no. 3, pp. 58-76. DOI: 10.17323/2713-2749.2021.3.58.76

\section{Introduction}

With the development of technologies, the relations associated with the use of objects of copyright and related rights have changed. To maintain a balance of interests between society and rightholders, in exchange for the use of works on the basis of licenses, the laws of many countries introduced a regime of remuneration to rightholders ${ }^{1}$, which is provided in Russian legislation by the relevant articles of the Civil Code ${ }^{2}$, and is implemented through the so-called blanket licenses [Boucher F.C., 1987: 1158] ${ }^{3}$ issued by collective management organizations (herein after referred as CMO). Such remuneration in accordance with Article 1226 of the Civil Code of the Rus-

${ }^{1}$ European Union. Remuneration of authors and performers for the use of their works and the fixations of their performances, 2015. Available at: http://publications.europa. eu/resource/cellar/c022cd3c-9a52-11e5-b3b7-01aa75ed71a1.0001.01/DOC_1 (accessed: 26.04.2020); http://www.aepo-artis.org/usr/files/di/fi/2/AEPO-ARTIS-study-on-performers-rights-1-December-2014-FINAL_201611291138.pdf (accessed: 26.04.2020), https:// www.cedar.nl/uploads/10/FileManager/SAA_white_paper_english_version.pdf (accessed: 26.04.2020), etc.

2 Articles 1263 (3), 1270 (6-8)(2), 1326 Civil Code of The Russian Federation

${ }_{3}$ Available at: https://scholarlycommons.law.wlu.edu/cgi/viewcontent.cgi?article=28 22\&context=wlulr; https://www.ascap.com/search-results?q=blanket\%20license; https:// www.songtrust.com/music-publishing-glossary/glossary-blanket-license; https://www. prsformusic.com/-/media/files/prs-for-music/licensing/application-forms/programmesales-licence-guide.pdf (accessed: 26.04.2020); 
sian Federation refers to "other rights" [Gongalo B.M., Kalyatin V.O., Kirillova M.Ya. et al., 2014: 85]. In accordance with clause 36 of the Resolution of the Plenum of the Supreme Court of the Russian Federation of 04.23.2019 $\mathrm{N} 10$ "On the application of part four of the Civil Code of the Russian Federation" and on the basis of clause 5 of Article 1229 of the Civil Code, the right to remuneration is included in the exclusive right, which also noted in the legal literature [Mikhailov S.M., Morgunova E.A., Ryabov A.A. et al., 2014: 70]. In accordance with clause 1 of article 1244 of the Civil Code, the collection and distribution of such remuneration is carried out by an accredited CMO, which receive accreditation from the Ministry of Culture of the Russian Federation for areas of activity directly established by the Civil Code. ${ }^{4}$ The identified areas of activity relate to the following use rights: public performance, broadcasting and / or cable retransmission.

Public performance by law means the presentation of a work in live performance or with the help of technical means (radio, television, etc.), as well as the display of an audiovisual work in a place open to the public, or in a place with a significant number of persons who do not belong to the ordinary family circle, regardless of whether the work is perceived at the place of its presentation or in another place at the same time as the presentation of the work (Article 1270 of the Civil Code; clause 93 of the Resolution of the Plenum of the Supreme Court of the Russian Federation).

Under the broadcasting or a cable retransmission, that is, under the communication to the public (including display or performance) on radio or TV, it should be understood as a direct broadcast of the work from the place of display or performance and repeatedly retransmission of the recorded performance. The broadcasting is carried out by TV or radio company in accordance with the terms of the license agreement concluded between it and the right holder or the Organization for Rights Management (Article 1270 of the Civil Code of the Russian Federation; $\$ 94$ of the Resolution of the Plenum of the Supreme Court of the Russian Federation).

These legal powers are widely used in various areas of our daily activities. The examples are the use of the phonograms in theatre performances, concerts, sports competitions (ice dancing, synchronous swimming, etc.), exhibitions, etc. The activity of radio stations, TV channels and cable operators is directly related to the legal power of broadcasting or / and cable retransmission, respectively. It is for such "classic" ways to use works / pho-

${ }^{4}$ Ministry of Culture of Russian Federation. Available at: URL: https://culture.gov.ru/ documents/akkreditatsiya/ (accessed: 25.09.2021) 
nograms the legislations of many countries provide for a mechanism for the implementation of copyright through the CMO.

In this regard, it is important to note the role of $\mathrm{CMO}$, whose activities have been considered from the very beginning as a compromise between copyright protection on the one hand, and the development of those activities in which the use of phonograms plays a significant role, on the other hand. It is the intermediary activities of CMO to represent the interests of copyright holders in collaboration with users, that provided that stable balance, which was and remains extremely important for the implementation of copyright.

However, with the development of the Internet and digital data transmission technologies (Mobile, Bluetooth, etc.) for users such as: Internet radio stations, Internet $\mathrm{TV}$, online cinemas, etc., the problem of legitimate use of works and phonograms is extremely acute. Modern Russian law does not give an unequivocal response, how existing norms allow you to use the traditional mechanism for obtaining the permission through the CMOs currently operating in the Russian Federation. Will the license from the CMO be sufficient to avoid additional claims from the copyright holders?

To answer these questions, it seems necessary first of all to apply to the analysis of the content of Internet rights as in Russian, and in international and foreign legislation. The Russian Federation is a member of all existing international author-legal contracts. Many copyright laws known to the Russian law were borrowed from international standards. Sometimes such borrowing happened "blindly", i.e. without a proper understanding of the content of the right and without a deep analysis of the relevant legal relations. The purpose of this article is the analysis of international treaties and norms of Russian law in terms of copyright regulation on the Internet.

\section{Genesis of the Internet copyright law on the international level}

Internet copyright in the meaning of the author's right to distribute his work in the digital environment appeared in Russian legislation in 2004. However, the emergence of this authority should be associated primarily with its recognition at the international level. In 1996, it was enshrined in two treaties of the World Intellectual Property Organization: the WIPO Copyright Treaty (hereinafter - WCT) and the WIPO Performances and Phonograms Treaty (hereinafter - WPPT), to which the Russian Federation joined in $2008 . .^{5}$ It should be noted that the term "Internet copyright"

5 Treaties for which WIPO is the depository. Available at: https://www.wipo.int/treaties/ru/ShowResults.jsp?lang=ru\&treaty_id=16 (accessed: 01.04.2020) 
is collective and refers not only to the Internet, but to the digital environment as a whole [Szczepańska B. 2004: 4] ${ }^{6}$ Already at the stage of the adoption of this power, it was noted that Internet technologies blurred the boundaries between two traditionally distinct groups of rights: the rights associated with obtaining a copy of the work (the right to distribute, the right to rent, etc.), and the rights not associated with receiving a copy (the right to public performance, the right to broadcast, etc.). ${ }^{7}$ In this regard, it was noted that there are two alternative approaches [Christie A.F., Dias E., 2005: 237-262] $]^{8}$, in particular: the application of the distribution right (UK, USA) [Benley L., Sherman B., 2004: 231] and the application of the right to communication to the public (France) [Lipzig D., 2002: 161]. The latest edition of the 1971 Berne Convention" already contained redundant provisions ${ }^{10}$, namely: "public performance", "communication to the public", "public communication", "broadcasting" and other forms transfer of a work in relation to a limited number of works [Ginsburg J.C., Treppoz E., 2015: 314]. That is why clause 1 of article 8 of the WCT specifically indicates the absence of any conflict and contradiction with the corresponding articles of the Berne Convention, providing for ways of distributing a work, in particular, articles 11 (1) (ii), 11 bis (1) (i), 11 bis (1) (ii), 11 ter (1) (ii), 14 (1) (ii) and 14 bis (1).

The dilemma about the form of providing the Internet copyright in an international treaty arose already at the stage of negotiations. Members of the WIPO Committees ${ }^{11}$ discussed two competing powers presented through the right of reproduction, and then, alternatively, either 1) with the granting of a wider distribution right, or 2) in conjunction with the corresponding communication right enshrined in the Berne Convention. However, the conflicting positions of the US and the EU led to a compro-

6 Available at: https://docs.lib.purdue.edu/cgi/viewcontent.cgi? article $=1717$ \&context=iatul (accessed: 20.05.2021)

7 WIPO. The Manual for the Agreements on Copyright and Neighboring Rights. Geneva, 2003. P. 207.

8 Available at: https://minerva-access.unimelb.edu.au/bitstream/handle/11343/25131/ Christie_Dias_The+new+light+of+communication.pdf;jsessionid=12079866CD6920944 2D5D7F90EAEB01A?sequence $=3$ (accessed: 15.04.2020)

9 The Berne Convention for the Protection of Literary and Artistic Works.

${ }_{10}$ Revision of the Berne Convention in Paris in 1971. Available at: https://www.wipo. int/treaties/ru/ip/berne/summary_berne.html (accessed: 15.04.2020)

${ }^{11}$ See in details: WIPO, Diplomatic Conference on certain copyright and neighboring rights questions Geneva, December 2 to 20, 1996, clauses 7.05, 7.07, 7.08, 7.12 etc. Available at: https://www.wipo.int/edocs/mdocs/diplconf/en/crnr_dc/crnr_dc_4.pdf (accessed: 15.04.2020) 
mise, "umbrella solution" [Peter K. Yu., 2010: 576], which was eventually included in the corresponding articles of the WCT and WPPT [WIPO, 2003: 208].

In this regard, according to a study by the US Copyright Office, at present we can talk about the existence of at least three approaches to the regulation of "Internet copyrights" in national legislation: ${ }^{12}$

the so-called "Approach identical to the international treaty", which implies full, or very close to the original with minor adjustments, copying of Article 8 WCT, as well as Articles 8, 14 WPPT. In this approach, the right to "make available" is part of the right to "communicate to the public". Thus, a broad approach to the right of communication to the public for use in the digital environment is being shaped. Since the communication to the public is a "traditional" right and was known to the law of many countries before the adoption of the WCT and WPPT, most countries, in particular the EU, chose this particular wording to "characterize the new property right, since it was formulated not as completely new one, but as an extension of some of the copyrights previously recognized internationally [Gavrilov E.P., 2005: 20];

an alternative approach, which, as a rule, considers the right to make available as a separate authority (this approach is used in Russia);

Statutory Silence approach: with this approach, the state, being a member of WCT and WPPT, does not in any way change the position of national legislation. The use of works in the digital environment is classified in terms of the existing scope of rights to use the work that existed before the accession to these agreements, as well as the appearance of digital use (USA).

Such a difference in approaches to understanding the right to Internet law could not but affect national legislation, in particular, of Russia, the USA and the EU.

\section{Comparative analysis of Internet copyright law in the jurisdictions of Russia, the USA and the EU}

The "Internet copyright law" presented in Russian legislation was first adopted in 2004 as amendments to the Law "On Copyright and Related

12 US Copyright Office. The making available right in The United States. A Report of the Register of copyrights, 2016, Appendix E. Survey of foreign laws regarding statutory approaches to the right of making available. Available at: https://www.copyright.gov/docs/ making_available/making-available-right.pdf, (accessed: 15.04.2020) 
Rights" of 09.07.1993 N 5351-1 (hereinafter referred to as the Copyright Law). ${ }^{13}$ The emerging norms could not but cause a certain resonance in society, because completely new relations emerging in an environment previously unknown to mankind were subject to legal regulation. The of copyright regulation on the Internet still remains highly controversial [WunschVincent S., 2013: 9]; [Edwards L., 2010].

The Copyright Law granted the author (Art.16), performer (Art.37) and phonogram producer (Art.38) the right to communicate the work (performance and phonogram), in such a way that any person can have access to it online from any place and at any time (the right to make available). The wording of these articles has been cited in a number of court decisions, without in-depth analysis of the norms. ${ }^{14}$

Despite the fact that in Russian legislation the "Internet copyright" has existed since 2004, its content and scope is still controversial. It seems that the new right to use the work was not fully regulated in the 1993 Law on Copyright and Related Rights, but only in such a version as to ensure the compliance of the Russian legislation with WCT [Gorlenko S.A., Kalyatin V.O., Kiriy L. L. et al. 2016: 76]. Some authors consider this Russian norm to be an unsuccessful copy of the corresponding article of the WTC [Kalyatin V.O., 2005: 3].

However, the current version of this authorization does not appear to cover all possible uses of works / phonograms on the Internet.

After the reform of civil legislation in 2008, the content of the right to "make available" underwent certain changes.

The current Civil Code of the Russian Federation grants Internet copyrights to the author (Article 1270), to the performer (Article 1317) and to the producer of the phonogram (Article 1324). The broad wording "making available" is used to refer to cases where works are posted on the Internet in such a way that anyone can access the work from anywhere and at any time of their choice. In this sense, "making available" should be understood as the granting of the right of access and further control over the transfer of the work [Rozhkova M.A., 2018: 55]. When comparing the content of the right to make available in the 1993 Law on Copyright and Related Rights and the Civil Code of the Russian Federation 2008, the following differ-

${ }^{13}$ Federal Law of 20.07.2004 N 72-FZ "On Amendments to the Law of the Russian Federation” On Copyright and Related Rights”. Rossiyskaya Gazeta. 03.08.1993.

${ }^{14}$ Resolution of the Thirteenth Arbitration Court of Appeal of 29.05.2009 in case No. A56-32763 / 2008 // SPS ConsultantPlus. 
ences are revealed: firstly, in the Civil Code, use is presented in "making available", as a way of presenting a work in a digital environment, and not in "broadcasting", which, probably, in the opinion of the legislator, differs from the activities of TV and radio organizations and cable operators; secondly, in the Civil Code of the Russian Federation there is no concept of "interactive mode", but it is understood that communication to the public is associated with the use of works on the Internet.

The content of this right was perceived critically by Russian researchers. In particular, it was noted that "making available to the public" is not a right of use at all, but a result that can be achieved in various ways, for example, by transmitting a work by radio or TV [Kalyatin V.O., 2005: 3]. Vitaly Kalyatin also emphasizes that "making it public is not a way of using a work that is typical exclusively for the Internet; it is not a way of using a work at all" [Kalyatin V.O., 2004: 3]. A number of researchers noted that this right should be considered either as a separate power, for example, reproduction [Pogulyaev V.V., Vaipan V.A., Lyubimov A.P., 2006: 77], duplication of the right of retransmission by cable [Eremenko V.I., 2005: 68-75], or as a complex of rights, consisting of the right to reproduction, public display, public performance, broadcast and retransmission to the public by cable [Gavrilov E.P., 2005]. We agree with many researchers Vitaly Kalyatin, Eduard Gavrilov and others who questioned the need to recognize the "right to make available" as a separate power. Indeed, those powers that were previously known to copyright fully correspond to the volume and nature of the use of works. Only the environment and the method of delivery of the works have changed. The legislation of the Russian Federation before the changes in 2004 was completely dispensed with by those powers - reproduction and distribution - which were known to Russian law.

This is the approach used in US law, where Internet copyright law was implemented with the adoption of the DMCA (Digital Millennium Copyright Act) in $1998 .{ }^{15}$ However, the DMCA does not contain any specific "internet" entitlement. This is due to the position of the United States, according to which the use of works on-line is actions within the existing exclusive copyright powers, named in the law, related to reproduction, distribution, public display and public performance. ${ }^{16}$ In addition, to ex-

15 The Digital Millennium Copyright Act 1988. Available at: https://www.copyright. gov/legislation/dmca.pdf (accessed: 12.04.2020)

${ }^{16}$ Internet policy task force. U.S. Dep't of Commerce. Copyright policy, creativity, and innovation in the digital economy 15 (2013) ("Green Paper") Available at: http://www.uspto.gov/news/publications/copyrightgreenpaper.pdf, P14-18 (accessed: 12.04.2020) 
isting reproduction and public performance rights, the distribution right enacted in the 1976 Copyright Act applies to digital transmissions in the same amount as to tangible media.

In the United States, digital communication rights are applied only in relation to sound recordings (phonograms). After analyzing Internet contracts, as well as domestic legislation, considering the established judicial practice and the opinions of leading academic institutions, the US Copyright Office concludes that for the rest of the protected copyright works, a set of "traditional" use rights for the digital environment should be applied, which constitutes a single power to "make available". In this sense, for all issues arising both online and offline, the traditional mechanism for clearing rights from copyright holders will be applied. For example, the act of downloading a work complies with the distribution right (clause $3 \$ 106$ of the Copyright Act); the act of streaming (broadcasting) or displaying an image on the Internet is understood as the right of public performance and public display in accordance with clauses 4-6 \$106 of the Copyright Act, etc. ${ }^{17}$

The EU regards internet copyright as an extended power to communicate to the public that is set out in various Directives. ${ }^{18}$ The right to communicate to the public was broadly interpreted in EU Directive 2001/29 / EC of 22.05.2001 "On the harmonization of certain aspects of copyright and related rights in the information society", known as the InfoSoc Directive (hereinafter referred to as the Copyright Directive) ${ }^{19}$. One of the objectives of this directive was to establish uniform norms for the ratification of the

17 US Copyright Office. The making available right in The United States. A Report of the Register of copyrights. Wash., 2016, P.15-55. Available at: https://www.copyright.gov/ docs/making_available/making-available-right.pdf (accessed: 15.04.2020)

18 Directive 93/83/EEC of 27 September 1993 on the coordination of certain rules concerning copyright and rights related to copyright applicable to satellite broadcasting and cable retransmission; Directive 92/100/EEC of 19 November 1992 on rental right and lending right and on certain rights related to copyright in the field of intellectual property; Directive 96/9/EC of the European Parliament and of the Council of 11 March 1996 on the legal protection of databases; Directive 2014/26/EU of the European Parliament and of the Council of 26 February 2014 on collective management of copyright and related rights and multi-territorial licensing of rights in musical works for online use in the internal market); Directive (EU) 2019/790 of the European Parliament and of the Council of 17 April 2019 on copyright and related rights in the Digital Single Market and amending Directives 96/9/ EC and 2001/29/EC.

19 Directive 2001/29/EC of the European Parliament and of the Council of 22 May 2001 on the harmonization of certain aspects of copyright and related rights in the information society. Available at: https://eur-lex.europa.eu/legal-content/EN/ TXT/?uri=CELEX:32001L0029 (accessed: 01.10.2021) 
WCT and WPPT by the EU member states related to digital use, including with respect to making available, which should be understood in a broad sense, covering all types of communication for the public (Article 23 of the Introductory Provisions of the Copyright Directive). Article 3 of the Copyright Directive based on Article 8 WCT contains a provision according to which "... Member States shall provide authors with the exclusive right to authorize or prohibit any communication to the public of their works, by wire or wireless means, including the making available to the public of their works in such a way that members of the public may access them from a place and at a time individually chosen by them. "The first part of this article deals directly with the communication for general information, the second part - the so-called. "Sub-right" - known in Russian law as making availible rights, which is part of the basic right of communication to the public and cannot be interpreted outside this context [Koo J., 2019: 81]. Making available is an act of access for the transmission of a work on demand, and applies regardless of whether it is directly transmitted [Savola P., 2017: 3]. In the EU, communication to the public should be considered in two aspects: "traditional", associated with the use of works (phonograms) through public performance and broadcast / cable communication and "digital", i.e. use on the Internet [Koo J., 2019: 90]. A broad interpretation of the right of communication to the public on the Internet was given by the European Court of Justice, which noted that "... the concept of 'communication to the public', within the meaning of Article 3 (1) of Directive $2001 / 29$, must be interpreted as meaning that it covers a retransmission of the works included in a terrestrial television broadcast:... .by means of an internet stream made available to the subscribers of that other organization who may receive the retransmission by logging on to its server... ". 20

A broad interpretation of the right to communicate to the public is observed even in those Directives that do not explicitly mention this right [Frankel S., Gervais D., 2016: 217], as well as in the legislation of many EU countries. ${ }^{21}$ In particular, the Swedish copyright law, like other Nordic countries, contains a rule on the universal right to make available, which is covered by the right of communication to the public, by means of wired

${ }^{20}$ Judgment of The Court (Fourth Chamber) in CaseC-607/11 7 March 2013. Available at: https://eur-lex.europa.eu/LexUriServ/LexUriServ.do?uri=CELEX:62011CJ0607:EN:HT ML (accessed: 22.04.2020)

${ }^{21}$ The International Literary and Artistic Association. Report and opinion on the making available and communication to the public in the Internet environment - focus on linking techniques on the Internet, pp. 4, 5. Available at: https://www.alai.org/en/assets/ files/resolutions/making-available-right-report-opinion.pdf (accessed: 15.04.2020) 
and wireless communications (paragraphs 1, 4 of article 2 of the Law on copyright). ${ }^{22}$ German copyright law deals with several entitlements within a broad approach to the right to communicate to the public, including the right to make available (Art 15 Urheberrechtsgesetz). ${ }^{23}$ The UK Copyright Act recognizes as violation of the right to communications for the public to misconduct by bringing a work to the public, a right that is reserved to the copyright holder in section 16 (1) (d) of the said act. ${ }^{24}$

\section{The Internet copyright law in Russian legislation}

Based on the analysis of the content of Internet law in international treaties - Article 8 of the WCT and in the corresponding articles of the WPPT, as well as regulation in US and EU law, we can note the peculiarities of the Russian approach to Internet copyright law. In particular, international treaties grant the author and the producer of the phonogram the exclusive right to permit any communication to the public ${ }^{25}$, by wire or by means of wireless communication, which includes the right to make available to the public. It is this right - any communication for the public, along with the right of distribution - that became the object of study in the adoption of WIPO international Internet treaties in the aspect of digital use.

According to the WIPO Glossary, communication to the public should be understood to mean the provision of a work, performance, phonogram or broadcast, appropriately perceived by anyone, not limited to specific individuals belonging to a private group. It is broader than publication and includes uses such as public performance, broadcasting, communicating to the public by wire, or receiving a broadcast signal directly [WIPO, 1980: 42]. This approach differs from the right to make available which exists in Russian legislation. Disclosing the concept of "message", the Civil Code of the Russian Federation indicates that such is any action by means of which a work becomes available for auditory and (or) visual perception, regardless of its actual percep-

22 Act (1960:729) on Copyright in Literary and Artistic Works (as amended up to Act (2018:1099). Available at: https://wipolex.wipo.int/en/text/495847 (accessed: 15.04.2020)

${ }^{23}$ Act on Copyright and Related Rights (Copyright Act, as amended up to Act of September 1, 2017). Available at: https://wipolex.wipo.int/en/text/474282 (accessed: 15.04.2020)

${ }^{24}$ Copyright, Designs and Patents Act of 1988. Available at: https://assets.publishing. service.gov.uk/government/uploads/system/uploads/attachment_data/file/772818/copyright-designs-and-patents-act-1988.pdf (accessed: 15.04.2020)

${ }_{25}$ WIPO Copyright Treaty. Available at: https://wipolex.wipo.int/en/text/295166 (accessed: 20.07.2021) 
tion by the public (Article 1270 of the Civil Code). Such an expanded approach to the term "communication", on the one hand, fully complies with paragraph 1 of Article 8 of the WCT, but at the same time, in the wording of this article, it is limited to broadcasting on radio or TV. Understanding the wording of the right to "communicate to public" is further complicated by its content used in the Civil Code of the Russian Federation. If in the first sentence of clause 7 of Article 1270 of the Civil Code we are talking about "communication to the public", then the next sentence contains only the term "communication", without the qualifying feature "to the public."

Thus, in relation to the action associated with the "communication", two mutually exclusive conclusions can be drawn based on the content of article 1270 of the Civil Code of the Russian Federation:

communication is any action, including also broadcasting on radio and TV (extended approach);

communication is only broadcasting on radio and television (narrow approach).

In the light of the provisions of Article 8 WCT, the resolution of the current contradiction is extremely important, since it affects the qualification of certain actions related to the use of objects of copyright and related rights on the Internet and in another digital way (mobile operators, etc.).

According to Article 1329 of the Civil Code of the Russian Federation, an organization that carries out on-air and cable broadcasting is a legal entity. In turn, Art. 31 of the Law of the Russian Federation of 27.12.1991 "On the Mass Media" TV or radio broadcasting is carried out by the broadcaster on the basis of a license granted by an authorized federal body. Obtaining a broadcasting license is not required if the broadcasting of a TV channel or radio channel is carried out unchanged under an agreement with a broadcaster holding a license to broadcast a TV channel or radio channel. The latter should be attributed to individuals such as the cable operator.

In accordance with the Law "On Licensing" ${ }^{26}$, TV and radio broadcasting are possible only with an appropriate license issued by the federal licensing body, which is currently the Federal Service for Supervision of Communications, Information Technology and Mass Media (Roskomnadzor). ${ }^{27}$ The

${ }^{26}$ Federal Law of 04.05.2011 N 99-FZ (as amended on 02.07.2021) “On licensing certain types of activities". Rossiyskaya Gazeta. 06.05.2011.

${ }^{27}$ Federal Service for Supervision of Communications, Information Technology and Mass Media. Available at: https://rkn.gov.ru/mass-communications/license/p156/ (accessed: 15.10 .2021 ) 
Law on Mass Media in the Russian Federation considers only a legal entity as an applicant for a license. Consequently, only legal entities are those subjects that carry out communication of a work to the public by radio or TV.

At the same time, the distribution of a work on the Internet can be carried out, among other things, by individuals, as well as by persons who, although they carry out entrepreneurial activities, are not legal entities (for example, individual entrepreneurs, self-employed). In addition, these persons can not only relay programs of TV and radio companies, but also use their content. Nothing also prevents individuals from creating Internet radio and television channels on their own. And this is observed everywhere today: personal channels on YouTube, videos on TikTok, etc.

In this sense, the subject of the use of works / phonograms on the Internet has no meaning for the copyright holders. Another thing is important: the very fact of use. Also of interest is the method and type of use of the work, which allows you to choose a mechanism for clearing user rights.

\section{Features of using works on the Internet}

Referring to the Internet copy right, represented in Russian law, it should be noted that it is associated with the provision of access to the work / phonogram to any third parties who can access such objects at any time from anywhere. However, as noted above, this too narrow approach to this right does not always allow us to characterize it correctly.

Currently, the following ways of using works in the digital environment (which are not legal categories) can be distinguished:

simultaneous (streaming) broadcasting is a method of broadcasting in which a person carries out "traditional" broadcasting by radio and TV waves (off-line) with simultaneous transmission on the Internet (online). Since, as indicated above, only legal entities can communicate a work to the public on radio or television, therefore, this form of presentation (use) of a work is typical for all radio and TV channels that have a broadcasting license ${ }^{28}$;

digital broadcasting is a method of broadcasting only in a digital environment (Internet, through mobile applications, etc.). In this case, there is no need for a person to obtain any license, as well as to register as a special entity (individual entrepreneur, legal entity);

making the work available to the public. These users include online cinemas, digital services, etc. They generally do not stream;

${ }^{28}$ See official web sites of radio broadcasters. Available at: URL: https://europaplus.ru/, https://rusradio.ru/, https://www.1tv.ru/, https://tvzvezda.ru/ (accessed: 15.02.2021) 
mixed method: is most often typical for such digital platforms as Yandex Music, YouTube, Spotify, etc., on which both digital broadcasting and making the work available to the public is carried out. ${ }^{29}$

As noted above, these ways of using works in the digital environment are conditional. Another thing is important - in all cases, the use of works occurs and, therefore, a "clearing" of rights is required. And it is the definition of this mechanism - through direct licensing by the rightsholder or through blanket licenses issued by the $\mathrm{CMO}$ - that is the problem that needs to be resolved.

\section{Simultaneous (streaming) broadcasting}

Simultaneous communication on the air and on the Internet turns into a problem for broadcasting organizations, for which it is not always clear what is the act of communication on the Internet and in mobile television, and how to qualify the object of the broadcasting? As M.V. Prokofieva correctly notes, according to article 1225 of the Civil Code, messages on the air or by cable of radio or television broadcasts are the results of intellectual activity, which are granted legal protection as an object of related rights. Simultaneous communication on the air and on the Internet turns into a problem for broadcasting organizations, for which it is not always clear what is the act of communication on the Internet and in mobile TV, and how to qualify the object of the broadcasts? At the same time, when a broadcaster broadcasts its TV channel on the Internet, these methods are not considered as broadcasting the work on the air and, based on the meaning of the norm, are not protected, although in this case the same program of the TV channel is broadcast in real time without changes as on the air and via the Internet, which leads to infringement of the rights of the broadcasting organization [Prokofieva M.V., 2009: 6].

Regarding the obtaining permission to use a work by broadcasting organizations, it is enough to request a license from the relevant CMO. ${ }^{30}$ However, the Civil Code of the Russian Federation does not contain a clear answer whether these licenses cover cases of simultaneous (streaming) messages on the Internet and in a mobile application? If so, is it possible to

29 Official web sites of the providers. Available at: URL: https://music.yandex.ru/ home, https://www.youtube.com/?gl=RU, https://www.spotify.com/ru-ru/why-not-available/ (accessed: 05.05.2020)

${ }^{30}$ Licenses issued by CMO. Available at: URL: http://rao.ru/for-users/to-radio/; http:// rosvois.ru/contract-tv/ (accessed: 05.10.2021) 
extend such licenses to other cases of the message, for example, only online [Ivanov N.V., 2017: 17]?

It seems that the answer should be yes: the blanket license issued by the relevant PMCS is sufficient for streaming. When broadcasting simultaneously, as well as when broadcasting online or in a mobile application, only the receiving method changes for the user.

Digital and Internet broadcasting differs from TV or radio broadcasting only in the transmission medium (IP networks, cable or wireless networks, instead of radio), and coincides in capabilities - the listener in both cases cannot independently choose the content played at a given moment in time, and save it for later listening by regular means. In case of stopping listening to the channel, the user resumes listening not from the place where he left off, but connects to the actual message of the work that is currently being broadcast on the corresponding channel [Sytenko G.I., Vilinov A.A., 2010: 7]. Based on this, Internet broadcasting can also be equated to a special form of broadcasting, but there are no restrictions on a person - a legal entity, individual entrepreneur, etc., which carries it out. As noted above, the presence / absence of special subjects, as well as permits (in this case, licenses for broadcasting activities), does not exclude the very fact of use and requires obtaining a blanket license from the CMO, by analogy with Art. 1244 of the Civil Code of the Russian Federation).

In the case of using a work by making available to the general public, attention should be paid to the work to which access is provided on the Internet. When accessing certain objects, for example, audiovisual works, as well as user content on social networks (eg., Vkontakte) and video hosting (eg., YouTube, online cinemas, etc.), users do not create a request for works that constitute the content of such objects. For example, when watching a movie in an online cinema, the user, by analogy with offline cinemas, refers directly to the film, but not to the musical work used in it. In this sense, it makes no difference for the authors of a piece of music whether it is a public performance, broadcast, or the making a film available to the public. Watching a movie through any special service on the Internet does not differ in any way from watching it in an offline environment (cinema, TV channel, etc.). The only difference is the access to the work in terms of the time of its presentation: in the offline environment, access is possible at a set time by the person performing the public performance and / or broadcasting, while in the digital environment the work is available at any time and from any place at the request of the user.

For persons carrying out the lawful use of audiovisual works both online and offline, the mechanism for obtaining permission from copyright 
holders is also the same. In particular, both offline and online cinemas, as well as TV channels, must obtain the corresponding right to use the audiovisual work. However, in no case does the existence of licensing agreements with rightholders exempt licensees from paying remuneration to authors, provided for in clause 3 of Article 1263 of the Civil Code.

The following thesis is also important: the disposing a work on the Internet or in another digital environment does not exclude the fact that it is used in different ways. ${ }^{31}$ In particular, in accordance with para 89 of the Resolution of the Plenum of the Supreme Court of Russia of April 23, 2019 No. 10, recording a copy of a work on an electronic medium with the subsequent provision of access to this work to any person from anywhere at any time (also on the Internet) is the exercise of two powers that are part of the exclusive right: the right to reproduce (subparagraph 1 of para 2 of Article 1270 of the Civil Code of the Russian Federation) and the right to make available to the public (subparagraph 11 of para 2 of Article 1270 of the Civil Code of the Russian Federation).

We must agree with the position of the Plenum of the Supreme Court that the power to make available to the public is impossible without the power to reproduce. Indeed, in order for a work to become available on the Internet, it must first be uploaded to the server.

However, one should not be limited only to the specified powers. In certain cases, it can be argued that the power to "make available" is also correlated with the power to broadcast and perform in public. In the examples mentioned above, in particular, in streaming, the communication of the work to the public is actually broadcast. In turn, when providing an audiovisual work for general information, it should be stated that it is also broadcast and / or publicly performed.

Singling out as a separate power as bringing it to the public, the legislator only pursued the goal of emphasizing the environment of use different from the offline one, but no more. As noted above, the use of a work in a digital environment is a collective concept (by which the Plenum understands an information and telecommunications network, including the Internet), does not mean that there is no use of "traditional" powers. It is important to note here that a high level of legal protection can and should be interpreted to mean that copyright holders can control the proper use of their works and receive appropriate remuneration [Depreeuw S., 2014: 616].

31 There are exceptions related to access to the work, for example, age restrictions, subscription access, etc. However, these exceptions do not replace the general rule for granting access to a work. 


\section{Conclusion}

Analysis of international treaties, as well as regulatory provisions regarding the regulation of powers related to the use of works / phonograms on the Internet in the United States and the EU shows that this power is presented in a broad interpretation, which makes it possible to clear rights through the legal mechanisms existing provided for by the Civil Code of the Russian Federation. This mechanism is implemented through the system of collective management of rights. A broad approach to Internet law allows flexible application of current legislation to ensure the interests of copyright holders and users, while maintaining the balance necessary for business development. Thus, the stability and stability of legal relations is ensured, which do not depend on the development of technologies.

The existing mechanisms in the Civil Code, if properly interpreted, also allow the current $\mathrm{CMO}$ to collect remuneration for the represented groups of copyright holders from users performing streaming, as well as the presentation of musical and audiovisual works on demand. A broad approach to existing powers does not so much expand the powers of national CMO, but rather serve as a guarantee for the normal functioning of users on the Internet. Otherwise, a serious revision of the current rules will be required, which at the current moment will negatively affect not only the copyright holders, but also the users, who may be subject to legal claims for violation of rights, which is associated with the actual suspension of the activities of law-abiding users.

\section{I国 References}

1. Benley L., Sherman B. (2004) Intellectual Property Law: Copyright. Saint Petersburg: Juridicheskiy Center Press, 231 p. (In Russ.).

2. Boucher F.C. (1987) Blanket Music Licensing and Local Television: A Historical Accident in Need of Reform. Washington \& Lee University Law Review, no. 44, p. 1157.

3. Civil Code of the Russian Federation (2018) Copyright. Copyright related rights. Article-by-article commentary to chapters 69-71. B.M. Gongalo, V.O. Kalyatin, M. Ya. Kirillova et al. SPS Consultant Plus. (In Russ.).

4. The civilian concept of intellectual property in the system of Russian law (2018) Rozhkova M.A. (ed.). SPS Consutant Plus. (In Russ.).

5. Christie A., Dias E. (2005) The New Right of Communication in Australia. Sydney Law Review, vol. 27, no. 2 , pp. 237-262. 
6. Commentary on the Civil Code of the Russian Federation (2016) Vol. 1. Gorlenko S.A., Kalyatin V.O., Kiriy L.L. et al. SPS Consutant Plus. (In Russ.).

7. Depreeuw S. (2014) The variable scope of the exclusive economic rights in copyright. Cham: Kluwer Law International, p. 616.

8. Edwards L. (2010) The Role and Responsibility of Internet Intermediaries in the Field of Copyright and Related Rights. Geneva: WIPO, 73 p.

9. Eremenko V.I. (2005) Changes in the legislation of the Russian Federation on copyright and related rights. SPS Consultant Plus. (In Russ.).

10. Fiscor M. (2002) Collective management of copyright and related rights. Geneva: WIPO, p. 113.

11. Frankel S., Gervais D. (2016) The Internet and the Emerging Importance of New Forms of Intellectual Property. Cham: Kluwer Law International, p. 217.

12. Gavrilov E.P. (2005) Commentary on the Law on Copyright and Related Rights (itemized). SPS Consultant Plus. (In Russ.).

13. Gavrilov E.P. (2005) Some issues of copyright and related rights. Economika i pravo = Economy and law, no. 1, p.1. (In Russ.).

14. Ginsburg J., Treppoz E. (2015) International copyright law: U.S. and E.U. perspectives. Cheltenham: Edward Elgar, p. 314.

15. Intellectual property law: current issues (2014) S.M. Mikhailov, E.A. Morgunova, A.A. Ryabov et al. SPS Consultant Plus. (In Russ.).

16. Ivanov N.V. (2017) Legal regulation of the use of musical works in TV programs. Zhurnal suda po intellektualnym pravam = Journal of the Intellectual Rights Court, no. 17, pp. 6-13. (In Russ.).

17. Kalyatin V.O. (2005) Legal issues of using work in the Internet. Informatcionnoe pravo = Information Law, no. 1, pp. 16-20. (In Russ.).

18. Koo J. (2019) The Right of Communication to the Public in EU Copyright Law. Oxford: Hart Publishing, pp. 58-81.

19. Lipzig D. (2002) Copyright and related rights. Moscow: UNESCO Publishing House, p. 161.

20. MacGuigan F. (2015) Making available, communication to the public \& user interactivity: An analysis of the application of communication and performing rights to licensed music streaming services and the subsequent impact on performers. L.: University of Westminster. P.21.

21. Peter K. (2010) Digital Copyright Reform and Legal Transplants in Hong Kong. University of Louisville Law Review. vol. 48, pp. 726.

22. Pogulyaev V.V., Vaipan V.A., Lyubimov A.P. (2006) Commentary on the Law of the Russian Federation "On Copyright and Related Rights" (itemized). SPS Consultant Plus. (In Russ.). 
23. Savola P. (2017) EU Copyright Liability for Internet Linking. JIPITEC, no. 8 , pp. $138-150$.

24. Szczepańska B. (2004) Digital is not different - copyright in digital environment. Warszawa: Purdue University, $10 \mathrm{p}$.

25. Sytenko G.I., Vilinov A.A. (2010) Topical issues of regulation of relations for the protection of copyright and related rights on the Internet. Kultura: upravlenie, ekonomika, pravo = Culture: management, economics, law, no. 2, pp. 7-11. (In Russ.).

26. Wunsch-Vincent S. (2013) The Economics of Copyright and the Internet: Moving to an Empirical Assessment Relevant in the Digital Age. Geneva: WIPO, $18 \mathrm{p}$.

\section{Information about the author:}

E.R. Valdez-Martinez - Senior Lecturer.

The article was submitted 27.10.2020; approved after reviewing 03.02.2021; accepted for publication 18.05.2021. 